Original Article

\title{
Hyperhomocysteinemia as an Independent Risk Factor for Coronary Heart Disease. Comparison with Conventional Risk Factors
}

\author{
Hiper-homocisteinemia como fator de risco independente para doença coronariana: \\ comparação com fatores de risco convencionais
}

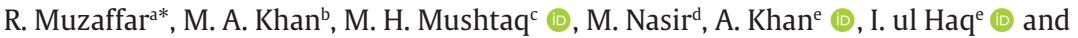 \\ J. Muhammad ${ }^{\mathrm{f}}$ (D) \\ aRashid Latif Medical College, Department of Nutritional Sciences, Lahore, Pakistan \\ bUniversity of Lahore, Department of Public Health, Lahore, Pakistan \\ 'University of Veterinary and Animal Sciences, Department of Epidemiology and Public Health, Lahore, Pakistan \\ dUniversity of Veterinary and Animal Sciences, Department of Food Science \& Human Nutrition, Lahore, Pakistan \\ 'The University of Haripur, Department of Public Health \& Nutrition, Haripur, Pakistan \\ 'The University of Haripur, Department of Microbiology, Haripur, Pakistan
}

\begin{abstract}
The present study was designed to evaluate the strength of association of raised plasma homocysteine concentration as a risk factor for coronary heart disease independent of conventional risk factor. It was a case control study conducted at Punjab Institute of Cardiology Lahore. A total of 210 subjects aged 25 to 60 years comprising of 105 newly admitted patients of CHD as cases and 105 age and sex matched healthy individuals with no history of CHD as control were recruited for the study. Fasting blood samples were obtained from cases and controls. Plasma homocysteine was analyzed by fluorescence polarization immunoassay (FPIA) method on automated immunoassay analyzer (Abbott IMX). Total cholesterol, triglyceride and HDL cholesterol were analyzed using calorimetric kit methods. The concentration of LDL cholesterol was calculated using Friedewald formula. The patients were also assessed for traditional risk factors such as age, sex, family history of CVD, hypertension, smoking and physical activity, and were compared with control subjects. The collected data was entered in SPSS version 24 for analysis and interpretation. The mean age in controls and experimental groups were $43.00 \pm 8.42$ years and $44.72 \pm 8.59$ years with statistically same distribution ( $\mathrm{p}$ - value $=0.144$ ). The mean plasma homocysteine for cases was $22.33 \pm 9.22 \mu \mathrm{mol} / \mathrm{L}$ where as it was $12.59 \pm 3.73 \mu \mathrm{mol} / \mathrm{L}$ in control group. Highly significant difference was seen between the mean plasma level of homocysteine in cases and controls $(\mathrm{p}<0.001)$.Simple logistic regression indicates a strong association of coronary heart disease with hyperhomocysteinemia (OR 7.45), which remained significantly associated with coronary heart disease by multivariate logistic regression (OR 7.10, 95\%C1 3.12-12.83, $\mathrm{p}=0.000$ ). The present study concludes that elevated levels of Plasma homocysteine is an independent risk factor for coronary heart disease independent of conventional risk factors and can be used as an indicator for predicting the future possibility for the onset of CVD.
\end{abstract}

Keywords: coronary heart disease, homocysteine, risk factor, cardiovascular diseases, family history.

\begin{abstract}
Resumo
O presente estudo foi desenhado para avaliar a força da associação da concentração elevada de homocisteína no plasma como um fator de risco para doença cardíaca coronária independente do fator de risco convencional. Foi um estudo de caso-controle realizado no Punjab Institute of Cardiology Lahore. Um total de 210 indivíduos com idade entre 25 e 60 anos, compreendendo 105 pacientes recém-admitidos de CHD como casos e 105 indivíduos saudáveis pareados por idade e sexo sem histórico de CHD como controle, foi recrutado para o estudo. Amostras de sangue em jejum foram obtidas de casos e controles. A homocisteína plasmática foi analisada pelo método de imunoensaio de polarização de fluorescência (FPIA) em analisador de imunoensaio automatizado (Abbott IMX). Colesterol total, triglicerídeos e colesterol HDL foram analisados usando métodos de kit calorimétrico. A concentração de colesterol LDL foi calculada pela fórmula de Friedewald. Os pacientes também foram avaliados para fatores de risco tradicionais, como idade, sexo, história familiar de DCV, hipertensão, tabagismo e atividade física, e foram comparados com indivíduos de controle. Os dados coletados foram inseridos no SPSS versão 24
\end{abstract}

*e-mail: rizwanamuzaffar@gmail.com

Received: February 24, 2021 - Accepted: April 19, 2021

This is an Open Access article distributed under the terms of the Creative Commons Attribution License, which permits unrestricted use, distribution, and reproduction in any medium, provided the original work is properly cited. 
para análise e interpretação. A média de idade nos grupos controles e experimentais foi de $43,00 \pm 8,42$ anos e $44,72 \pm 8,59$ anos com distribuição estatisticamente igual ( $p$-valor $=0,144$ ). A homocisteína plasmática média para os casos foi de $22,33 \pm 9,22 \mu \mathrm{mol} / \mathrm{L}$, enquanto no grupo controle foi de $12,59 \pm 3,73 \mu \mathrm{mol} / \mathrm{L}$. Diferença altamente significativa foi observada entre o nível plasmático médio de homocisteína em casos e controles $(\mathrm{p}<0,001)$. A regressão logística simples indica uma forte associação de doença cardíaca coronária com hiper-homocisteinemia (OR 7,45), que permaneceu significativamente associada com doença cardíaca coronária por multivariada regressão logística (OR 7,10, 95\% C1 3,12-12,83, p = 0,000). O presente estudo conclui que níveis elevados de homocisteína plasmática são fator de risco independente para doença cardíaca coronária, independentemente dos fatores de risco convencionais, e pode ser usado como um indicador para prever a possibilidade futura de aparecimento de DCV.

Palavras-chave: doença cardíaca coronária, homocisteína, fator de risco, doenças cardiovasculares, história familiar.

\section{Introduction}

The cardiovascular diseases (CVDs) are the leading public health challenge having maximum share of the morbidity and mortality worldwide (Feigin et al., 2016; Prabhakaran et al., 2018). The relevant literature describes that one of the major reasons of health loss in all regions of the world is still related with CVDs. The demographic and social transition of the last two three decades is associated with a reduction of CVDs in some areas but there is a minor or no change of the disease burden in most of the regions (Roth et al., 2017; Guilliams, 2004).

Among Cardiovascular disease, coronary heart disease is the most prevalent one accounting for major cause of all death (Santulli, 2013). Currently efforts are done to control this devastating disease the major focus has been shifted towards the preventive measures. Identification as well as effective management of conventional risk factors of coronary heart disease such as smoking, hypertension, dyslipidemia, family history and diabetes mellitus has brought the decline in incidence of coronary heart disease, no association of these factors has been observed in $15-20 \%$ of coronary heart disease patients and miss the opportunity of primary prevention (Smith Junior, 2006). The search of other risk factors continues and the one that has raised much attention is homocysteine. The role of homocysteine, which is a sulphur containing amino acid derived from the metabolism of essential amino acid methionine, has been emerged as a newly recognized risk factor (Ranjith and Devika, 2017). The raised plasma homocysteine level above 15 micromoles per liter $(\mathrm{mcmol} / \mathrm{L})$ is called hyperhomocysteinemia which promotes thrombosis and acts as a contributory factor for the adverse coronary events (Ranjith and Devika, 2017). Many studies have been conducted on the role of homocysteine (Hcy) as an independent risk factor for CHD. Moderately elevated concentration of plasma homocysteine is linked with risk of myocardial infarction (MI) independent of other risk factors for CHD (Stampfer et al., 1992). A twofold rise in MI among persons with plasma Hcy levels $>15 \mu \mathrm{mol} / \mathrm{L}$ has been noted in a national survey in the United States (Giles et al., 2000). Hcy studies collaboration research demonstrated that increase of about $3 \mu \mathrm{mol} / \mathrm{L}$ in plasma Hcy will increase $10 \%$ risk of cardiovascular events (Homocysteine Studies Collaboration, 2002). Some 10-20\% patients of CHD have been associated to increase level of plasma Hcy concentration. Dietary as well as hereditary factors may take part (Herrmann et al., 2006).

Homocysteine has emerged as a significant marker of vascular disease, especially in patients of Asian origin.
(Chambers et al., 2000). The burden of Coronary Heart Disease (CHD) is consistently on the rise in the developing countries including South Asian countries like Pakistan. A study about the prevalence of CHD among the urban population of Karachi concluded that the magnitude has increased tremendously since 1970 (Beaney et al., 2015). This escalation is most probably related with the changes of life style, eating pattern, lack of physical activity, smoking and psycho social issues.

A relevant study about the homocysteine level in the young Pakistani patients of coronary artery disease found an association between the disease and hyperhomocysteinemia (Ijaz et al., 2015). However, the literature is deficient about the strength of the association for homocysteine as a risk factor of CHD. Keeping in view this scenario, the present study was carried out to assess the strength of association between homocysteine level and CHD independent of conventional risk factors.

\section{Material and Methods}

\subsection{Study desings}

An analytical cross sectional study design was to conduct this study.

\subsection{Study area}

The current study was conducted at Punjab Institute of Cardiology (PIC). PIC is one of the country's leading cardiology institutes where large number of cardiac patients are brought from various parts of the country. It is located one of the most populated cities of the province and $2^{\text {nd }}$ highly populated in Pakistan.

\subsection{Sampling}

A total of 210 subjects aged 25-60 years comprising of 105 newly admitted patients of coronary heart disease at Punjab Institute of Cardiology were selected as cases and 105 matched healthy individuals as control were recruited. They were considered healthy on the basis that they were not having any cardiovascular disease or previous history of the problem. The cases were enrolled after proper clinical evidence confirmed by standard procedure. Similarly, the controls were selected from general population without any clinical disorders and no history of CHD. All the controls were symptomless on clinical examination. All cardiovascular laboratory tests were within normal 
limits and with normal ECG. Both the groups were also matched for age, gender and socioeconomic status.

\subsection{Exclusion criteria}

Subjects with a history of diabetes, renal impairment/ dysfunction/disorder, hepatitis, thyroid disorder, pregnancy and those taking antiepileptic drugs or any other drugs that affects the liver function, or any form of vitamin B complex during the past 6 months and those under lipid lowering treatment were not included in the study. The proposed study was approved by the ethical committee of the Institute (UVAS) and informed consent was obtained from each participant. The ethical committee approval certificate will be shared on request.

\subsection{Data collection}

Baseline data of the study population was collected using a pretested structured questionnaire to obtain information on demographic background, dietary habits, socioeconomic status, medical history, family history of coronary heart disease, physical activity and smoking habits. Height \& weight and blood pressure were measured whereas body mass index (BMI) was calculated.

\subsection{Sample collection and analysis}

After an overnight fast of 10-12 hours venous blood sample was drawn (under aseptic techniques) from each participant into an EDTA vacutainers. The vacutainers were placed on ice till the plasma was separated within 30 minutes of sample collection and were stored at $-20^{\circ} \mathrm{C}$ until analyzed. Total plasma homocysteine level was analyzed using Fluorescence Polarization Immunoassay (FPIA) method on automated immunoassay analyzer (Abbott, IMX). Serum was obtained for measurement of lipid profile using enzymatic colorimeter method (RANDOX, UK).

\subsection{Statistical analysis}

All collected data was analyzed by using SPSS version 24. Mean \pm S.D was used for quantitative data like age, homocysteine level and lipid profiles. Frequency (\%) was used for categorical data like gender. Independent sample t-test was applied to compare age, homocysteine levels and lipid profiles in both study groups while Mann Whitney U-test was applied for non-normal data. Risk analysis was carried out by calculating Odds ratio (OR) and 95\% Confidence Interval. Initially univariate analysis was done which was followed by multivariate logistic regression analysis. Normality of the data was conducted also. Variables were retained in the final model on the basis on their $p$ value less than 0.20 following one the previously reported assumption.

\section{Results}

Among the total 210 study participants, 105 were in the control group whereas 105 patients were with clinical evidence of coronary heart disease. Summarized the baseline profile of the study population (Table 1).
The age of the study population ranged between 25 to 60 years. The mean \pm SD (Standard deviation) age in control and experimental groups were $43.0 \pm 8.4$ years and $44.7 \pm 8.5$ years respectively. Among 105 cases 79 ( $75.2 \%)$ were males and 26 (24.8\%) were females. The control group comprised of 80 (76.2\%) males and 25 (23.8\%) females. The differences in the mean age and the male and females in the two groups were statistically not significant ( $\mathrm{p}=0.167$ and $\mathrm{p}=0.872$ respectively). Analysis of the socio-economic status of the study population showed that majority of the cases $66.7 \%$ and their control subjects (67.6\%) belonged to middle income group followed by low income group which was $22.9 \%$ and $20.0 \%$ in these groups respectively. Only $10.5 \%$ of cases and $12.4 \%$ of control group belonged to high income group. Statistically nonsignificant differences were seen $(\mathrm{p}=0.830)$. In addition, family history of CHD revealed that 14 (13.3\%) controls and 28 (26.7\%) cases reported that they had family history of CHD whereas 91 (86.7\%) controls and 77 (73.3\%) cases did $\operatorname{not}(\mathrm{p}=0.016)$ indicat that family history is a risk factor of CHD. Incidence of smoking was present in $44.7 \%$ of cases compared to $23.8 \%$ of controls indicating that smoking is a risk factor of CHD. No statistically significant differences (0.07) were obtained regarding physical activity between cases and controls. Physical inactivity was present in $34.3 \%$ of cases compared to $22.9 \%$ controls.

\subsection{Homocysteine of the study population}

We classified homocysteine as normal 5-15 $\mu \mathrm{mol} / \mathrm{L}$, moderate $>15-30 \mu \mathrm{mol} / \mathrm{L}$ and intermediate hyperhomocysteinemia $>30-100 \mu \mathrm{mol} / \mathrm{L}(14)$. In our study out of 105 cases $21 \%$ had normal level of homocysteine, $60 \%$ had moderate hyperhomocysteinemia and 19\% had intermediate hyperhomocysteinemia. The percentage of subjects in control group with normal homocysteine level was $66.7 \%$ whereas $33.3 \%$ had moderate hyperhomocysteinemia. None of the controls had intermediate hyperhomocysteinemia. The comparison showed highly significant difference $(\mathrm{p}=0.0001)$ between cases and controls (Table 2).

Mean \pm SD of Hcy for cases was $22.33 \pm 9.22 \mu \mathrm{mol} / \mathrm{L}$ whereas it was $12.59 \pm 3.73 \mu \mathrm{mol} / \mathrm{L}$ in control group. Highly significant difference was seen between the mean plasma level of Hcy in cases and controls ( $<<0.0001$ ) (Table 3).

To assess the possible strength of association of homocysteine and other conventional risk factors with coronary heart disease, the subjects exposed to risk factors were compared to the ones not exposed among the cases and controls. Simple logistic regression analysis indicates strong association of coronary heart disease with homocysteine. The Odds ratio (OR) for hyper homocysteinemia in coronary heart disease patients was 7.45 (95\% confidence interval: 4.055-14.039, p=0.000) indicating that risk of developing coronary heart disease is 7.45 times higher in cases than in controls. Odds of having CHD with family history, smoking, hypertension, physical activity, total cholesterol, triglyceride, HDL and LDL were 2.36 (95\% CI: 1.16-4.80, p = 0.024), 2.69 (95\% CI: 1.49-4.86, $\mathrm{p}=0.001), 1.34(95 \% \mathrm{CI}: 0.76-2.35, \mathrm{p}=0.388)$, 1.76(95\% CI: 0.95-3.23, p = 0.092) 1.85 (95\% CI: 1.03-3.33, 
Table 1. Demographic and Clinical Characteristics of the study population.

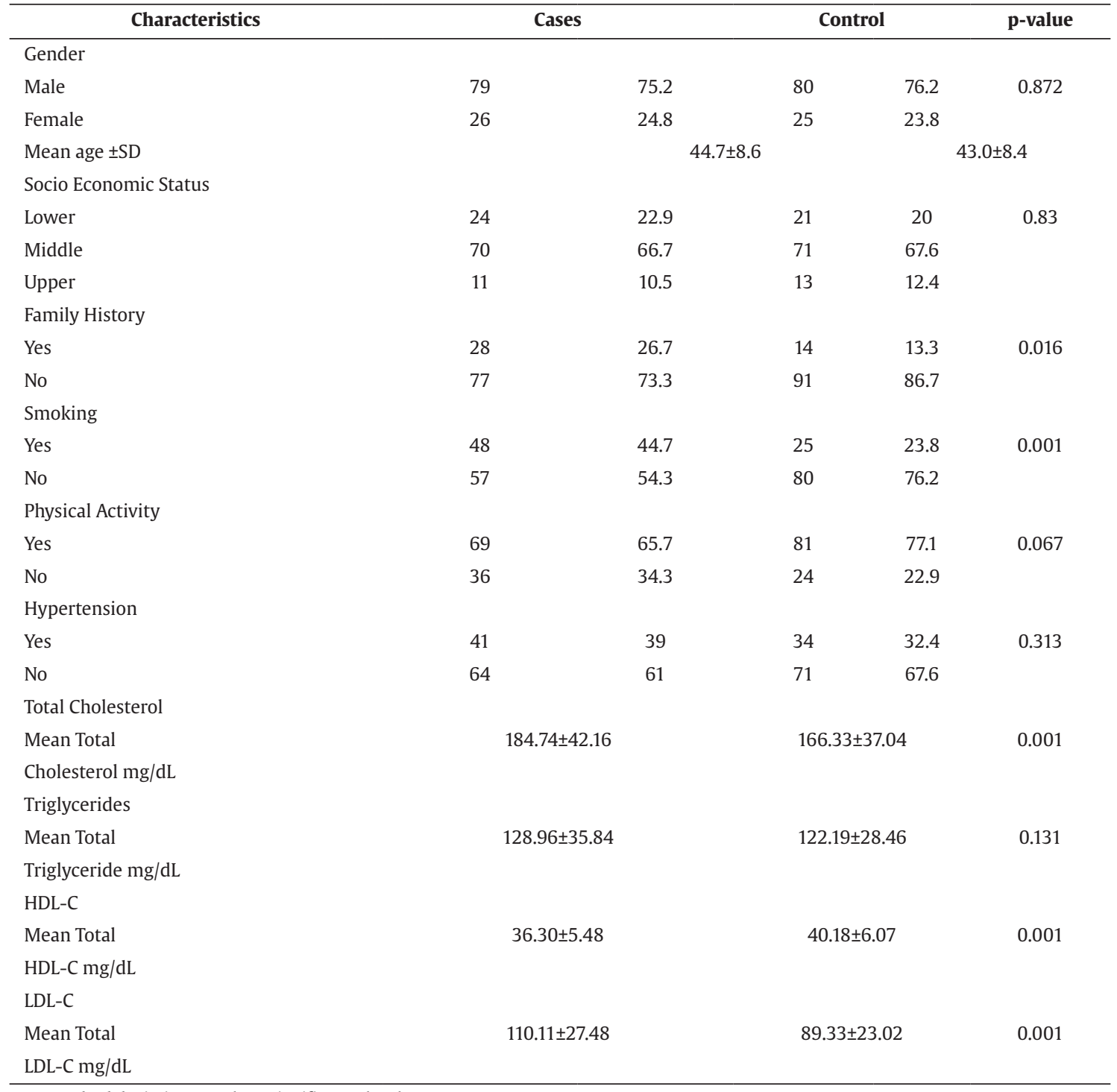

$\mathrm{SD}=$ standard deviation; $\mathrm{P}$-value $=$ significance level.

Table 2. Percentage of Subjects in Cases and Controls with Normal and Hyperhomocysteinemia.

\begin{tabular}{lccc}
\hline \multicolumn{1}{c}{ Plasma Homocysteine Level } & Cases n (\%) & Control n (\%) & P Value \\
\hline Normal $(5-15 \mu \mathrm{mol} / \mathrm{L})$ & $22(21.0)$ & $70(66.7)$ & 0.0001 \\
Moderate Hyperhomocysteinemia $(>15-30 \mu \mathrm{mol} / \mathrm{L})$ & $63(60.0)$ & $35(33.3)$ & \\
Intermediate Hyperhomocysteinemia $(>30-100 \mu \mathrm{mol} / \mathrm{L})$ & $20(19.0)$ & $0(0)$ & \\
\hline
\end{tabular}

P value $=$ level of significance at $95 \%$ confidence interval.

Table 3. Plasma level of homocysteine between cases and control groups.

\begin{tabular}{cccccc}
\hline & & Mean & S.D & IQR & P-Value \\
\hline $\begin{array}{c}\text { Homocysteine } \\
(\mu \mathrm{mol} / \mathrm{L})\end{array}$ & Control & 12.59 & 3.73 & 6.55 & $<0.0001$ \\
& Experimental & 22.33 & 9.22 & 6.50 & \\
\hline
\end{tabular}

P value $=$ level of significance at 95\% confidence interval. 
$\mathrm{p}=0.039), 1.58(95 \% \mathrm{Cl}: 0.84-2.96, \mathrm{p}=0.204) 2.51(95 \% \mathrm{CI}$ : $1.36-4.63, \mathrm{p}=0.004)$, and 2.81 (95\% Cl: $1.34-5.92, \mathrm{p}=0.008)$ respectively. (Table 4 )

After adjustment for confounding variables the multivariate logistic regression analysis showed that the risk odds ratio of homocysteine and family history was significantly raised. Of these two homocysteine had a strong positive association (OR7.10, 95\% CI: 3.12-12.84, $\mathrm{p}=0.000$ and $\mathrm{OR} 2.66,95 \% \mathrm{CI}: 1.13-6.32, \mathrm{p}=0.024)$ respectively (Table 5 ).

\section{Discussion}

Cardio vascular diseases (CVDs) comprised of the diseases of heart and blood vessels and thought to be responsible for one third of the total deaths in the world (Ganguly and Alam, 2015). It is based on evidence that these diseases are the global leading cause of death out of which low and middle-income countries accounts for around $80 \%$ to $86 \%$ of these deaths (Barolia and Sayani, 2017). The evidence from Pakistan as concluded that there is a rise of non-communicable diseases related risk factors (WHO, 2015). There are multiple risk and contributing factors due to which, it is nearly impossible to fix a single point for remedial measures. The present study was conducted to investigate the strength of plasma homocysteine level as a risk factor for coronary heart disease.

In the present study the mean \pm SD age of controls was $43.00 \pm 8.42$ and that of experimental group $44.72 \pm 8.59$ years. The mean ages observed in our study are lower than many other studies and approve recently observed trend in different Asian studies that comparatively younger aged people in Asia are being diagnosed with heart problems compared to other parts of the world. Puri et al. (2003) and Gupta et al. (2012) also reported young mean age of patients in their study (37.4 \pm 5.5 years, and 41 years respectively) validating our statement. In previous studies males were found at higher risk of heart problems (Shenoy et al., 2014). The gender distribution in our study was 79 (745.2\%) males and 26 (24.8\%) females in study groups. The stuwdy was mainly on male aligned as coronary artery disease afflicts young males more commonly than females. This gender difference can be ascribed to the fact that women are more or less sheltered from atherosclerosis until menopause due to protective effect of estrogen (Ridker et al., 1999).

Table 4. Risk of Coronary Heart Disease in Relation to Homocysteine and Conventional Risk Factors.

\begin{tabular}{|c|c|c|c|c|c|c|c|c|}
\hline \multirow{2}{*}{ Risk Factors } & \multirow{2}{*}{$\begin{array}{c}\text { Unadjusted } \\
\text { OR }\end{array}$} & \multicolumn{2}{|c|}{ 95\% C.I } & \multirow{2}{*}{ p-value } & \multirow{2}{*}{$\begin{array}{l}\text { Adjusted } \\
\text { OR }\end{array}$} & \multicolumn{2}{|c|}{ 95\% C.I } & \multirow{2}{*}{ Sig } \\
\hline & & Lower & Upper & & & Lower & Upper & \\
\hline Homocysteine & 7.54 & 4.05 & 14.03 & $0.000^{* *}$ & 7.10 & 3.59 & 14.50 & $0.000^{*}$ \\
\hline Smoking & 2.69 & 1.49 & 4.86 & $0.001^{* *}$ & 1.86 & 0.94 & 3.69 & 0.076 \\
\hline Hypertension & 1.34 & 0.76 & 2.35 & 0.388 & - & - & - & - \\
\hline Family History & 2.36 & 1.16 & 4.80 & $0.024^{* *}$ & 2.66 & 1.13 & 6.23 & $0.024^{*}$ \\
\hline Physical activity & 1.76 & 0.95 & 3.23 & $0.092^{*}$ & - & - & - & - \\
\hline Total Cholesterol & 1.85 & 1.02 & 3.33 & 0.039 & 0.836 & 0.40 & 1.73 & 0.630 \\
\hline Triglycerides & 1.58 & 0.84 & 2.96 & 0.204 & 1.094 & 0.49 & 2.43 & 0.825 \\
\hline HDL-C ${ }^{* *}$ & 2.51 & 1.36 & 4.63 & $0.004^{* *}$ & 1.87 & 0.91 & 3.84 & 0.087 \\
\hline LDL-C $C^{* * *}$ & 2.81 & 1.34 & 5.91 & $0.008^{* *}$ & 1.65 & 0.70 & 3.92 & 0.251 \\
\hline
\end{tabular}

HDL-C C $^{* *}$ High Density Lipoprotein Cholesterol; LDL-C ${ }^{* * *}=$ Low Density Lipoprotein Cholesterol; Only significant variables remain in model for multivariate logistic regression.

Table 5. Statistical Analysis using Multivariate Logistic Regression.

\begin{tabular}{cccc}
\hline & Odds Ratio (OR) & 95\% CI & P-Value \\
\hline Homocysteine & 7.10 & $3.59-14.50$ & $0.00^{*}$ \\
Smoking & 1.86 & $0.94-3.69$ & 0.076 \\
Family History & 2.66 & $1.13-6.23$ & $0.024^{*}$ \\
Total Cholesterol & 0.836 & $0.40-1.33$ & 0.630 \\
HDL-C & 1.87 & $0.91-3.84$ & 0.087 \\
LDL-C & 1.65 & $0.70-3.92$ & 0.251 \\
Triglycerides & 1.094 & $0.49-2.43$ & 0.825 \\
\hline
\end{tabular}

95\% Cl= 95\% confidence interval; HDL-C ${ }^{* *}=$ High density Lipid Cholesterol; LDL-C ${ }^{* * *}=$ Low density Lipid Cholesterol; Only significant variables remain in model for multivariate logistic regression. 


\subsection{Plasma homocysteine level of study population}

Our study findings support the hypothesis that increased plasma Hcy is a risk factor for CHD, independent of other risk factors. Mean plasma homocysteine level $(22.33 \pm 9.22 \mu \mathrm{mol} / \mathrm{L})$ in our study group was significantly higher ( $\mathrm{p}$-value $<0.0001$ ) than the control group $(12.59 \pm 3.73 \mu \mathrm{mol} / \mathrm{L})$. The results of our study are inconsistent with previous findings (Rahman et al., 2004; Gupta et al., 2012; Jain et al., 2003; Abraham and Cho, 2010; Puri et al., 2003) reporting similar observations of plasma homocysteine levels higher among study group as compared to controls. Our findings are also in line with the results of another similar study in which mean homocysteine level was found $38.34 \pm 15.25 \mu \mathrm{mol} / \mathrm{L}$ in cases and $9.41 \pm 4.22 \mu \mathrm{mol} / \mathrm{L}$ in the control groups (Smith Junior, 2006). The results of another case control study also favor the findings of present study and conclude a definite role of increased homocysteine as a risk for the CVD. However, a study conductedon a sample of 90 subjects including 30 cases and 60 controls and mean homocysteine level was found $21.93 \pm 10.50 \mu \mathrm{mol} / \mathrm{L}$ in cases and $14.34 \pm 4.79 \mu \mathrm{mol} / \mathrm{L}$ in the control study subjects (Karumarakkal and Manjalavil, 2017).

Our findings are also in agreement with other studies that reported an elevation in plasma Hcy levels in CHD patients. Lubos et al. (2007) and Agoston-Coldea et al. (2011) in their studies observed that there were significant differences in the mean levels of plasma Hcy between CHD patients $(24.59 \pm 6.14 \mu \mathrm{mol} / \mathrm{L})$ and in controls $(13.73 \pm 3.54 \mu \mathrm{mol} / \mathrm{L})$. However, a few studies have shown that there was no difference in plasma homocysteine concentration in CAD patients and controls. (Iqbal et al., 2005)

\subsection{Risk of coronary heart disease in relation to homocysteine and conventional risk factors}

Logistic regression analysis was used to estimate the risk association of CHD with homocysteine and traditional risk factors. The odds ratio and $95 \%$ confidence interval were determined by using SPSS 24 software.

Simple logistic regression analysis indicated strong association of CHD with hyperhomocysteinemia. The odds ratio for hyperhomocysteinemia was 7.45 (95\% CI: 4.05-14.03, P=0.000). Significant elevated levels of plasma homocysteine were observed in the patient group of CHD, when compared with controls. This can probably explain the high risk odds ratio associated with homocysteine. Traditional risk factors significantly associated with increased risk of CHD: smoking 2.70 times, hypertension 1.34 times, family history 2.40 times, hypercholesterolemia 1.85 and decreased HDL- cholesterol 2.52 times and increased LDL- cholesterol 2.82 times.

Multivariate logistic regression was performed to calculate adjusted odds ratio. Hyperhomocysteinemia remained significantly associated with $\mathrm{CHD}$ by multivariate logistic regression analysis (OR 7.10, 95\% CI: 3.59- 14.50, $\mathrm{P}=0.000$ ) indicating that patients with increased plasma levels of homocysteine had a seven times increased risk of developing CHD. The results of our study are similar to the other studies conducted by Puri et al.
(2003), (Masoomi et al., 2015) and (Ijaz et al., 2015) in which odds ratio were $6.05,5.05$ and 3.50 respectively. Helfenstein et al. (2005) and Speidl et al. (2011) found similar results $(\mathrm{OR}=4)$ for $\mathrm{MI}$ diagnosed non-invasive investigations. In the same way, Laghari et al. (2009) related that hyperhomocysteinemia increases the risk of $\mathrm{MI}$ in patients with type 2 diabetes. A study conducted by Xiao et al. (2011) reported a positive association between elevated levels of homocysteine and coronary artery disease (OR=1.61; 95\% CI 1.26-2.05). The mechanisms of how homocysteinemia induces coronary disease are poorly understood but there are evidences of an endothelial oxidative damage (Zhang et al., 2017), endothelial smooth muscle proliferation (Nishimoto et al., 2003), oxidation of low density lipoproteins (Halvorsen et al., 1996) and decrease in nitric oxide synthase (Fatini et al., 2005).

\section{Conclusion}

Increased level of plasma homocysteine was significantly higher than controls. Simple logistic regression analysis indicates a strong association of coronary heart disease with hyperhomocysteinemia. In the light of the forging facts it can be inferred that elevated levels of plasma homocysteine are an independent risk factor for coronary heart disease and can be used as an indicator for predicting the future possibility for the onset of CVD.

\section{References}

ABRAHAM, J.M. and CHO, L., 2010. The homocysteine hypothesis: still relevant to the prevention and treatment of cardiovascular disease. Cleveland Clinic Journal of Medicine, vol. 77, no. 12, pp. 911-918. http://dx.doi.org/10.3949/ccjm.77a.10036. PMid:21147945.

AGOSTON-COLDEA, L., MOCAN, T., GATFOSSE, M., LUPU, S. and DUMITRASCU, D.L., 2011. Plasma homocysteine and the severity of heart failure in patients with previous myocardial infarction. Cardiology Journal, vol. 18, no. 1, pp. 55-62. PMid:21305486.

BAROLIA, R. and SAYANI, A.H., 2017. Risk factors of cardiovascular disease and its recommendations in Pakistani context. JPMA. The Journal of the Pakistan Medical Association, vol. 67, no. 11, pp. 1723-1729. PMid:29171568.

BEANEY, K.E., COOPER, J.A., SHAHID, S.U., AHMED, W., QAMAR, R., DRENOS, F., CROCKARD, M.A. and HUMPHRIES, S.E., 2015. Clinical utility of a coronary heart disease risk prediction gene score in UK healthy middle aged men and in the Pakistani population. PLoS One, vol. 10, no. 9, pp. e0139651. http://dx.doi. org/10.1371/journal.pone.0130754.

CHAMBERS, J.C., OBEID, O.A., REFSUM, H., UELAND, P., HACKETT, D., HOOPER, J., TURNER, R.M., THOMPSON, S.G. and KOONER, J.S., 2000. Plasma homocysteine concentrations and risk of coronary heart disease in UK Indian Asian and European men. Lancet, vol. 355, no. 9203, pp. 523-527. http://dx.doi.org/10.1016/ S0140-6736(99)93019-2. PMid:10683001.

FATINI, C., SOFI, F., GORI, A.M., STICCHI, E., MARCUCCI, R., LENTI, M., CASINI, A., SURRENTI, C., ABBATE, R. and GENSINI, G.F., 2005. Endothelial nitric oxide synthase- 786T $>$ C, but not $894 \mathrm{G}>\mathrm{T}$ and $4 \mathrm{a} 4 \mathrm{~b}$, polymorphism influences plasma homocysteine concentrations in persons with normal vitamin status. Clinical 
Chemistry, vol.51, no. 7, pp. 1159-1164. http://dx.doi.org/10.1373/ clinchem.2005.048850. PMid:15905312.

FEIGIN, V.L., ROTH, G.A., NAGHAVI, M., PARMAR, P., KRISHNAMURTHI, R., CHUGH, S., MENSAH, G.A., NORRVING, B., SHIUE, I., NG, M., ESTEP, K., CERCY, K., MURRAY, C.J.L., FOROUZANFAR, M.H., and GLOBAL BURDEN OF DISEASES, INJURIES AND RISK FACTORS STUDY 2013 AND STROKE EXPERTS WRITING GROUP, 2016. Global burden of stroke and risk factors in 188 countries, during 1990-2013: a systematic analysis for the Global Burden of Disease Study 2013. Lancet Neurology, vol. 15, no. 9, pp. 913-924. http://dx.doi.org/10.1016/S1474-4422(16)30073-4. PMid:27291521.

GANGULY, P. and ALAM, S.F., 2015. Role of homocysteine in the development of cardiovascular disease. Nutrition Journal, vol. 14, pp. 6. http://dx.doi.org/10.1186/1475-2891-14-6. PMid:25577237.

GILES, W.H., CROFT, J.B., GREENLUND, K.J., FORD, E.S. and KITTNER, S.J., 2000. Association between total homocyst (e) ine and the likelihood for a history of acute myocardial infarction by race and ethnicity: results from the Third National Health and Nutrition Examination Survey. American Heart Journal, vol. 139, no. 3, pp. 446-453. http://dx.doi.org/10.1016/S0002-8703(00)90088-7. PMid:10689259.

GUILLIAMS, T.G., 2004. Homocysteine: a risk factor worth treating. The Standard, vol. 6, pp. 1-7.

GUPTA, S.K., KOTWAL, J., KOTWAL, A., DHALL, A. and GARG, S., 2012. Role of homocysteine \& MTHFR C677T gene polymorphism as risk factors for coronary artery disease in young Indians. The Indian Journal of Medical Research, vol. 135, no. 4, pp. 506-512. PMid:22664498.

HALVORSEN, B., BRUDE, I., DREVON, C.A., NYSOM, J., OSE, L., CHRISTIANSEN, E. and NENSETER, M., 1996. Effect of homocysteine on copper ion-catalyzed, azo compound-initiated, and mononuclear cell-mediated oxidative modification of low density lipoprotein. Journal of Lipid Research, vol. 37, no. 7, pp. 1591-1600. http://dx.doi.org/10.1016/S0022-2275(20)39141-0. PMid:8827529.

HELFENSTEIN, T., FONSECA, F.A., RELVAS, W.G., SANTOS, A.O. DABELA, M.L., MATHEUS, S.C., D'ALMEIDA, V., TUFIK, S., SOUZA, F.G., RODRIGUES, P.R., TAGLIERI, R., SOUSA, E.F. and IZAR, M.C., 2005. Prevalence of myocardial infarction is related to hyperhomocysteinemia but not influenced by $\mathrm{C} 677 \mathrm{~T}$ methylenetetrahydrofolate reductase and A2756G methionine synthase polymorphisms in diabetic and non-diabetic subjects. Clinica Chimica Acta; International Journal of Clinical Chemistry, vol. 355, no. 1-2, pp. 165-172. http://dx.doi.org/10.1016/j. cccn.2004.12.002. PMid:15820491.

HERRMANN, M., TABAN SHOMAL, O., HÜBNER, U., BÖHM, M. and HERRMANN, W., 2006. A review of homocysteine and heart failure. European Journal of Heart Failure, vol. 8, no. 6, pp. 571-576. http://dx.doi.org/10.1016/j.ejheart.2005.11.016. PMid: 16504575 .

HOMOCYSTEINE STUDIES COLLABORATION, 2002. Homocysteine and risk of ischemic heart disease and stroke: a meta-analysis. Journal of the American Medical Association, vol. 288, no. 16, pp. 2015-2022. http://dx.doi.org/10.1001/jama.288.16.2015. PMid:12387654.

IJAZ, A., ZAMIR, S., SATTAR, A., JAN, R., ALI, S. and WAZIR, F., 2015. Homocysteine levels in younger patients with coronary artery disease in Pakistan. Gomal Journal of Medical Sciences, vol. 13, no. 4, pp. 202-206.

IQBAL, M., ISHAQ, M., KAZMI, K., YOUSUF, F., MEHBOOBALI, N., ALI, S., KHAN, A. and WAQAR, M., 2005. Role of vitamins B6, B12 and folic acid on hyperhomocysteinemia in a Pakistani population of patients with acute myocardial infarction. Nutrition, Metabolism, and Cardiovascular Diseases, vol. 15, no. 2, pp. 100-108. http:// dx.doi.org/10.1016/j.numecd.2004.05.003. PMid:15871858.

JAIN, S., V, H.R., KUMARI, S. and KHULLAR, M., 2003. Plasma homocysteine levels in Indian patients with essential hypertension and their siblings. Renal Failure, vol. 25, no. 2, pp. 195-201. http://dx.doi.org/10.1081/JDI-120018720. PMid:12739826.

KARUMARAKKAL, J. and MANJALAVIL, M.R., 2017. Homocysteine and lipid profile in patients with coronary artery disease. Journal of Medical Science and Clinical Research, vol. 5, no. 9, pp. 28105-28109. https://dx.doi.org/10.18535/jmscr/v5i9.122.

LAGHARI, A.H., MEMON, A.N., SHAH, A.M., AHMAD, S. and MEMON, M.S., 2009. Hyperhomocysteinemia, a risk factor for myocardial infarction in patients with Type-2 Diabetes in Southrern Sindh, Pakistan. Pakistan Journal of Nutrition, vol. 8, no. 11, pp. 17531755. http://dx.doi.org/10.3923/pjn.2009.1753.1755.

LUBOS, E., LOSCALZO, J. and HANDY, D.E., 2007. Homocysteine and glutathione peroxidase-1. Antioxidants \& Redox Signaling, vol. 9, no. 11, pp. 1923-1940. http://dx.doi.org/10.1089/ars.2007.1771. PMid:17822368.

MASOOMI, M., AZDAKI, N. and SHAHOUZEHI, B., 2015. Elevated plasma homocysteine concentration in opium-addicted individuals. Addiction $\mathcal{E}$ Health, vol. 7, no. 3-4, pp. 149-156. PMid:26885351.

NISHIMOTO, S., TAWARA, J., TOYODA, H., KITAMURA, K. and KOMURASAKI, T., 2003. A novel homocysteine-responsive gene, smap8, modulates mitogenesis in rat vascular smooth muscle cells. European Journal of Biochemistry, vol. 270, no. 11, pp. 2521-2531. http://dx.doi.org/10.1046/j.1432-1033.2003.03626.x. PMid: 12755708.

PRABHAKARAN, D., JEEMON, P., SHARMA, M., ROTH, G.A., JOHNSON, C., HARIKRISHNAN, S., GUPTA, R., PANDIAN, J.D., NAIK, N., ROY, A., DHALIWAL, R.S., XAVIER, D., KUMAR, R.K., TANDON, N., MATHUR, P., SHUKLA, D.K., MEHROTRA, R., VENUGOPAL, K., KUMAR, G.A., VARGHESE, C.M., FURTADO, M., MURALEEDHARAN, P., ABDULKADER, R.S., ALAM, T., ANJANA, R.M., ARORA, M., BHANSALI, A., BHARDWAJ, D., BHATIA, E., CHAKMA, J.K., CHATURVEDI, P., DUTTA, E., GLENN, S., GUPTA, P.C., JOHNSON, S.C., KAUR, T., KINRA, S., KRISHNAN, A., KUTZ, M., MATHUR, M.R., MOHAN, V., MUKHOPADHYAY, S., NGUYEN, M., ODELL, C.M., OOMMEN, A.M., PATI, S., PLETCHER, M., PRASAD, K., RAO, P.V., SHEKHAR, C., SINHA, D.N., SYLAJA, P.N., THAKUR, J.S., THANKAPPAN, K.R., THOMAS, N., YADGIR, S., YAJNIK, C.S., ZACHARIAH, G., ZIPKIN, B., LIM, S.S., NAGHAVI, M., DANDONA, R., VOS, T., MURRAY, C.J.L., REDDY, K.S., SWAMINATHAN, S., DANDONA, L. and INDIA STATE-LEVEL DISEASE BURDEN INITIATIVE CVD COLLABORATORS, 2018. The changing patterns of cardiovascular diseases and their risk factors in the states of India: the Global Burden of Disease Study 1990-2016. The Lancet. Global Health, vol. 6, no. 12, pp. e1339-e1351. http:// dx.doi.org/10.1016/S2214-109X(18)30407-8. PMid:30219317.

PURI, A., GUPTA, O., DWIVEDI, R., BHARADWAJ, R., NARAIN, V. and SINGH, S., 2003. Homocysteine and lipid levels in young patients with coronary artery disease. The Journal of the Association of Physicians of India, vol. 51, pp. 681-685. PMid:14621037.

RAHMAN, M., BROWN, C.D., CORESH, J., DAVIS, B.R., ECKFELDT, J.H., KOPYT, N., LEVEY, A.S., NWACHUKU, C., PRESSEL, S., REISIN, E., WALWORTH, C. and ANTIHYPERTENSIVE AND LIPID-LOWERING TREATMENT TO PREVENT HEART ATTACK TRIAL COLLABORATIVE RESEARCH GROUP, 2004. The prevalence of reduced glomerular filtration rate in older hypertensive patients and its association with cardiovascular disease: a report from the Antihypertensive and Lipid-Lowering Treatment to Prevent Heart Attack Trial. 
Archives of Internal Medicine, vol. 164, no. 9, pp. 969-976. http://dx.doi.org/10.1001/archinte.164.9.969. PMid:15136305.

RANJITH, R. and DEVIKA, P., 2017. Clinical correlation between plasma homocysteine level and coronary artery disease in Indian patients. World Journal of Cardiovascular Diseases, vol. 7, no. 12, pp. 477-485. http://dx.doi.org/10.4236/wjcd.2017.712047.

RIDKER, P.M., MANSON, J.E., BURING, J.E., SHIH, J., MATIAS, M. and HENNEKENS, C.H., 1999. Homocysteine and risk of cardiovascular disease among postmenopausal women. Journal of the American Medical Association, vol. 281, no. 19, pp. 1817-1821. http://dx.doi. org/10.1001/jama.281.19.1817. PMid:10340369.

ROTH, G.A., JOHNSON, C., ABAJOBIR, A., ABD-ALLAH, F., ABERA, S.F., ABYU, G., AHMED, M., AKSUT, B., ALAM, T., ALAM, K., ALLA, F., ALVIS-GUZMAN, N., AMROCK, S., ANSARI, H., ÄRNLÖV, J., ASAYESH, H., ATEY, T.M., AVILA-BURGOS, L., AWASTHI, A., BANERJEE, A., BARAC, A., BÄRNIGHAUSEN, T., BARREGARD, L., BEDI, N., BELAY KETEMA, E., BENNETT, D., BERHE, G., BHUTTA, Z., BITEW, S., CARAPETIS, J., CARRERO, J.J., MALTA, D.C., CASTAÑEDA-ORJUELA, C.A., CASTILLO-RIVAS, J., CATALÁLÓPEZ, F., CHOI, J.Y., CHRISTENSEN, H., CIRILLO, M., COOPER, L. Jr., CRIQUI, M., CUNDIFF, D., DAMASCENO, A., DANDONA, L., DANDONA, R., DAVLETOV, K., DHARMARATNE, S., DORAIRAJ, P., DUBEY, M., EHRENKRANZ, R., EL SAYED ZAKI, M., FARAON, E.J.A., ESTEGHAMATI, A., FARID, T., FARVID, M., FEIGIN, V., DING, E.L., FOWKES, G., GEBREHIWOT, T., GILLUM, R., GOLD, A., GONA, P., GUPTA, R., HABTEWOLD, T.D., HAFEZI-NEJAD, N., HAILU, T., HAILU, G.B., HANKEY, G., HASSEN, H.Y., ABATE, K.H., HAVMOELLER, R., HAY, S.I., HORINO, M., HOTEZ, P.J., JACOBSEN, K., JAMES, S., JAVANBAKHT, M., JEEMON, P., JOHN, D., JONAS, J., KALKONDE, Y., KARIMKHANI, C., KASAEIAN, A., KHADER, Y., KHAN, A., KHANG, Y.H., KHERA, S., KHOJA, A.T., KHUBCHANDANI, J., KIM, D., KOLTE, D., KOSEN, S., KROHN, K.J., KUMAR, G.A., KWAN, G.F., LAL, D.K., LARSSON, A., LINN, S., LOPEZ, A., LOTUFO, P.A., EL RAZEK, H.M.A., MALEKZADEH, R., MAZIDI, M., MEIER, T., MELES, K.G., MENSAH, G., MERETOJA, A., MEZGEBE, H., MILLER, T., MIRRAKHIMOV, E., MOHAMMED, S., MORAN, A.E., MUSA, K.I., NARULA, J., NEAL, B., NGALESONI, F., NGUYEN, G., OBERMEYER, C.M., OWOLABI, M., PATTON, G., PEDRO, J., QATO, D., QORBANI, M., RAHIMI, K., RAI, R.K., RAWAF, S., RIBEIRO, A., SAFIRI, S., SALOMON, J.A., SANTOS, I., SANTRIC MILICEVIC, M., SARTORIUS, B., SCHUTTE, A., SEPANLOU, S., SHAIKH, M.A., SHIN, M.J., SHISHEHBOR, M., SHORE, H., SILVA, D.A.S., SOBNGWI, E., STRANGES, S., SWAMINATHAN, S., TABARÉS-SEISDEDOS, R., TADELE ATNAFU, N., TESFAY, F., THAKUR, J.S., THRIFT, A., TOPOR-MADRY, R., TRUELSEN, T., TYROVOLAS, S., UKWAJA,
K.N., UTHMAN, O., VASANKARI, T., VLASSOV, V., VOLLSET, S.E., WAKAYO, T., WATKINS, D., WEINTRAUB, R., WERDECKER, A., WESTERMAN, R., WIYSONGE, C.S., WOLFE, C., WORKICHO, A., XU, G., YANO, Y., YIP, P., YONEMOTO, N., YOUNIS, M., YU, C., VOS, T., NAGHAVI, M. and MURRAY, C., 2017. Global, regional, and national burden of cardiovascular diseases for 10 causes, 1990 to 2015. Journal of the American College of Cardiology, vol. 70, no. 1, pp. 1-25. http://dx.doi.org/10.1016/j.jacc.2017.04.052. PMid:28527533.

SANTULLI, G., 2013. Epidemiology of cardiovascular disease in the 21st century: updated updated numbers and updated facts. Journal of Cardiovascular Disease Research, vol. 1, no. 1, pp. 1.

SHENOY, V., MEHENDALE, V., PRABHU, K., SHETTY, R. and RAO, P., 2014. Correlation of serum homocysteine levels with the severity of coronary artery disease. Indian Journal of Clinical Biochemistry, vol. 29, no. 3, pp. 339-344. http://dx.doi.org/10.1007/s12291013-0373-5. PMid:24966483.

SMITH JUNIOR, S.C., 2006. Current and future directions of cardiovascular risk prediction. The American Journal of Cardiology, vol. 97, no. 2A, pp. 28-32. http://dx.doi.org/10.1016/j. amjcard.2005.11.013. PMid:16442934.

SPEIDL, W.S., KASTL, S.P., HUBER, K. and WOJTA, J., 2011. Complement in atherosclerosis: friend or foe? Journal of Thrombosis and Haemostasis, vol. 9, no. 3, pp. 428-440. http://dx.doi.org/10.1111/ j.1538-7836.2010.04172.x. PMid:21155967.

STAMPFER, M.J., MALINOW, M.R., WILLETT, W.C., NEWCOMER, L.M., UPSON, B., ULLMANN, D., TISHLER, P.V. and HENNEKENS, C.H., 1992. A prospective study of plasma homocyst (e) ine and risk of myocardial infarction in US physicians. Journal of the American Medical Association, vol. 268, no. 7, pp. 877-881. http://dx.doi. org/10.1001/jama.1992.03490070059042. PMid:1640615.

WORLD HEALTH ORGANIZATION - WHO, 2015. Noncommunicable diseases progress monitor 2015. Geneva: WHO.

XIAO, Q., SHANG, F., XU, X., LI, Q., LU, C. and LIN, J.-M., 2011. Specific detection of cysteine and homocysteine in biological fluids by tuning the $\mathrm{pH}$ values of fluorosurfactant-stabilized gold colloidal solution. Biosensors E Bioelectronics, vol. 30, no. 1, pp. 211-215. http://dx.doi.org/10.1016/j.bios.2011.09.013. PMid:21978483.

ZHANG, Z., WEI, C., ZHOU, Y., YAN, T., WANG, Z., LI, W. and ZHAO, L., 2017. Homocysteine induces apoptosis of human umbilical vein endothelial cells via mitochondrial dysfunction and endoplasmic reticulum stress. Oxidative Medicine and Cellular Longevity, vol. 2017, pp. 5736506. http://dx.doi.org/10.1155/2017/5736506. PMid:28630659. 